\title{
MASS TIMBER CONSTRUCTION IN AUSTRALIA AND NEW ZEALAND-STATUS, AND ECONOMIC AND ENVIRONMENTAL INFLUENCES ON ADOPTION
}

\author{
David C. Evison* \\ Associate Professor \\ School of Forestry \\ University of Canterbury, Christchurch \\ New Zealand \\ E-mail: david.evison@ canterbury.ac.nz \\ Paul D. Kremer \\ Research Fellow \\ The University of Melbourne \\ Melbourne, Australia \\ E-mail: paul.kremer@unimelb.edu.au \\ Jason Guiver \\ Project Development Manager \\ Nelson Pine Industries Ltd. \\ Nelson, New Zealand \\ E-mail: jason.guiver@nelsonpine.co.nz \\ (Received January 2018)
}

\begin{abstract}
Mass timber construction in Australia and New Zealand uses three main materials-laminated veneer lumber, glue laminated timber and cross-laminated timber (CLT). This article focuses on the use of mass timber in nonresidential construction-the use in single-family homes and apartments is not considered. In Australia and New Zealand, mass timber building technology has moved from being technologically possible to being a feasible alternative to reinforced concrete and steel construction. It has not taken over a large market share in either market and, as such, has not been a disruptive technology. The major changes in this market in the past 5-10 yr in Australia and New Zealand have been the development of new industrial capacity in CLT and the acquisition of computer controlled machining equipment to facilitate prefabrication of wooden building components. The development of new codes and standards and design guides is underway. The drivers of future growth in market share are expected to include more clients putting a higher weight on the various environmental benefits of building in wood, reduction in the real and perceived professional risk for builders and architects specifying mass timber construction, and fuller participation in the supply chain for timber buildings (from design to construction) by timber building specialists. Government policies to encourage the use of timber may also be helpful. Engineers and architects will continue to learn - through experience-how to optimize building construction methods to take advantage of the specific features and qualities of timber as a construction method.
\end{abstract}

Keywords: Mass timber construction, nonresidential buildings, prefabrication, design, LVL, Glulam, CLT.

\section{INTRODUCTION}

In this article, mass timber construction (MTC) is defined as "construction where the predominant structure of the building is timber." This includes

\footnotetext{
* Corresponding author
}

both post and beam construction, and panelized or honeycomb construction. Post and beam construction includes both gravity, and momentresisting frames (which are specifically designed to resist lateral forces such as those experienced in earthquakes). Mass timber construction uses components that are not available through the 
merchant supply chain, and, as such, it does not include the dimension lumber products used in "stick-frame" construction. The main materials used in MTC in Australia and New Zealand are laminated veneer lumber (LVL), glue laminated timber (Glulam) and cross-laminated timber (CLT). This article focuses on use of mass timber in nonresidential construction-the use in singlefamily homes and apartments is not considered.

Mass timber construction does not mean that the buildings are made entirely of wood. Almost all buildings are a composite of a number of materials-wood, steel, and concrete, as well as other materials. The mix of these materials will depend on the customer requirements and the specific demands of the site. It may sometimes also depend on the knowledge and experience of the professionals in the design and build phases. In this case, there is a need to provide more information about the new technologies that are available, such as wood, and it is hoped this article might contribute to better information on mass timber.

This article aims to review the relative environmental and economic position of mass timber compared with concrete and steel, and to understand the potential barriers to greater use of mass timber. Specifically, this article will explore the following:

1. What is the status of mass timber as a construction method in Australia and New Zealand? Overall, how is this technology perceived? What is the role of wood in the construction industry now, and what have been the learnings over the past $5 \mathrm{yr}$ ?

2. What are the factors affecting the economics and competitiveness of MTC?

3. What are the factors affecting environmental performance of mass timber?

4. What is the potential role of mass timber in the future, and what are the barriers to achieving this potential?

\section{STATUS OF MASS TIMBER AS A CONSTRUCTION MATERIAL IN AUSTRALIA AND NEW ZEALAND}

Mass timber construction uses products such as CLT, Glulam and LVL. Frequently, these materials are used in combination to take advantage of the best features of each for the building structure. As components are prefabricated, off-site MTC manufacturing ensures labor on-site is kept to a minimum (Yates et al 2008), resulting in significant reduction in site-based labor costs. MTC use has a number of environmental benefits compared with traditional construction (typically concrete and steel) methods and approaches, including carbon sequestration (Depro et al 2008). Timber manufacturing also uses less energy than concrete or steel, (Lehmann and Fitzgerald 2012) and it is a more readily renewable and recyclable resource when compared with alternative materials. A primary advantage, according to Kremer and Symmons (2015), is found in a reduction of the project timeframes because of off-site manufacturing and reduced on-site assembly. Large engineered-timber elements are designed and produced in manufacturing facilities and delivered to site for assembly and finishing. Given the natural characteristics of the timber used in MTC and the grade of the adhesives used in its manufacture, these structural members can achieve similar strength properties to those of concrete for a similar thickness (Wood Solutions 2013), allowing timber to substitute for concrete. LVL has a similar compressive strength parallel to the grain (38 MPa.) as concrete.

Dunn (2015) calculated the theoretical savings to be gained from using MTC when compared with purely traditional forms of construction. A comparison of four commercial building types assessing the differences in costs associated with using timber compared with concrete and steel. The report assessed a seven-story office building, an eight-story apartment building, a two-story aged care facility, and an industrial shed.

Each of the projects was designed and independently assessed (costs and other input factors) using timber as the primary construction material with a comparison material/s (conventional concrete-framed or steel-framed building) in an urban location-Sydney, Australia. Overall, the results of the study revealed constructing in timber had lower costs than the nontimber solution. The cost advantage for the eight-story 
apartment building was $2.2 \%$, the single-story industrial shed $(9.4 \%)$, the seven-story office building $(12.4 \%)$, and the two-story aged care facility $(13.9 \%)$. The precise location of the savings varied along with the unique qualities of the projects. For example, timber columns within the office building cost more than concrete $(+41 \%)$, yet the requirement for columns within the apartment building was negligible (because of a different approach to design), resulting in considerable savings $(-92 \%)$. The cost savings for the office and apartment building were generally in the costs associated with construction program savings (generally 6 wk) over the concrete solution. Dunn (2015) also reports that costs savings would have been greater had it not been for the fire protection to some structural components, additional fire engineering costs and the costs of termite protection.

Such differentiated channels to market require a shift in thinking and take time to establish and function adequately for MTC to become widely accepted. Presently MTC occupies a niche position in Australia and New Zealand. However, the development of MTC solutions for midrise and high-rise buildings could pose a considerable challenge to traditional concrete and steel construction. In terms of material costs comparisons, a primary difference in marketing MTC concerns the accurate calculation of material volume. If estimates are not accurate the cost may be grossly exaggerated, anecdotally up to $10 \%$. To accurately quote MTC projects the use of computeraided 3D modeling is required. Computer designs are able to assist with costing estimates, including connection details of each panel, structural thickness of members and required spanning, number of panel lifts required on-site (craning panels into place), optimization of panel design in accordance with the overall architecture of the project, and detailing the effective containerization and shipping of panels domestically and internationally, if required.

Page (2007) noted that in New Zealand, selection of material type was frequently a choice between reinforced concrete and steel. The selection of the material is made by the architect working with the engineer, and the choice may depend on the engineer's expertise. This will tend to reinforce the statusquo choice of materials. Page (2007) identified industrial buildings, office and government administration buildings, and retail and education buildings as the types that predominate the value of building work. However, Page (2007) also pointed out that farm and industrial buildings make up more than half the floor area of all new buildings and additions. Page (2007) provided two scenarios for future increase in wood use in construction:

A moderate scenario assumes timber will be used for low-rise buildings up to three storys and industrial and farm buildings. It also assumes a cost-effective roof span solution $(20-40 \mathrm{~m})$ can be developed, and a substantial focus on governmentfunded buildings - education, health, and administration because of sustainability considerations and government procurement policies. This moderate scenario is estimated to require an additional $53,000 \mathrm{~m}^{3}$ of timber for construction.

The optimistic scenario includes buildings up to six storeys. It assumes the delivery of drop-in floor systems and the adoption of timber for use in commercial buildings, where sustainability and Green Star rating systems give more recognition to timber. The optimistic scenario is assumed to lead to the use of $75,000 \mathrm{~m}^{3}$ of timber, beyond what is considered business-as-usual.

McGregor et al (2011) surveyed engineers to understand barriers to the use of LVL in singlestory nonresidential buildings. The authors found that there was a lack of evidence of cost competitiveness for LVL compared with steel and that the biggest barriers to greater uptake were a lack of experienced contractors, the required sizes for structural members, and the availability of prefabricators. Survey respondents also suggested that negative customer perceptions of fire resistance and uniformity may have limited the use of LVL. Although they recognized that LVL was more sustainable, with a lower carbon footprint than steel, this did not have a major impact on material selection. 
Evison (2015) reported on interviews conducted in Christchurch, New Zealand, in 2013 and 2014 after the building stock in Christchurch was severely damaged by a number of large earthquakes. At that time, there was significant public concern about the risk of injury and death from earthquakes, concern about the suitability of Christchurch soils (in some areas) for building high-rise buildings, and a rethink of the principle that buildings should be designed primarily to protect the occupants from injury. The idea of resilient and repairable buildings had emerged, along with a view that building codes needed to be revised and updated to reflect the learnings from the recent earthquakes.

The building owners or developers, the architects, engineers, and builders were all interviewed to understand the experiences they had with mass timber through the process of concept design and build. All buildings studied were originally conceived using mass timber because the owners wanted this type of construction. The role of fabrication in successful adoption was stressed by the builders, engineers and architects and was seen as one of the key requirements for adoption of MTC, through the reduction in costs, and enhancing the ability of mass timber buildings to compete with the well-established alternatives of reinforced concrete, and steel. At that time, the supply chains for steel and concrete were much better developed and supported existing practices in the construction industry better.

A survey was carried out in 2016 and 2017 in Christchurch (Bruneau and MacRae 2017) based on a study of 74 buildings constructed in the Christchurch central business district. The authors reported the number of buildings constructed with steel, reinforced concrete, and timber in ratio 10:10:1, whereas floor area was in the ratio 79:20:1. This is because steel and, to a lesser extent, concrete are used in larger buildings.

The building philosophy has changed after the Canterbury earthquake sequence-whereas previously the main design target was to prevent the loss of life in an earthquake, there is an increasing belief that this is not sufficient with an additional goal of producing structures that incur less damage and are easier to inspect and repair or reinstate (Bruneau and MacRae 2017). These are called low-damage systems. In principle these would increase the resilience of the building stock, with better business continuity after an earthquake. However, the authors stress that the definitions of "low damage" are not yet clear.

The marked shift to steel was attributed to the New Zealand legislative framework allowing new systems, perceptions of low damage and repairability of steel structures, current low price of steel, fast erection time, and economical flooring systems compatible with steel. The relative lightness of steel compared with reinforced concrete and the prevalence of soils with poor engineering properties, and the popularity of lowdamage technologies that are easy to connect to steel structures were also noted as important considerations.

"Timber construction, emphasized as a renewable resource, will remain novel, as most developers are less confident about using timber in their projects..." (Bruneau and MacRae 2017).

New Zealand is relatively well-endowed with LVL capacity, with three plants (owned by Carter Holt Harvey, Nelson Pine Industries, and Juken New Zealand) with a capacity of between $300,000 \mathrm{~m}^{3}$ and $400,000 \mathrm{~m}^{3}$ output per year. There are two main manufacturers of Glulam (TimberLab Solutions Ltd, Auckland and Hunter Laminates, Nelson) and one CLT plant, in Nelson (XLam) with a capacity of around 15,000 and $10,000 \mathrm{~m}^{3} / \mathrm{yr}$, respectively. A major New Zealand sawmiller (Red Stag) has recently announced its intention to build another CLT plant in New Zealand. There are three large-scale computerbased machining tools (CNC machines) operated by Timberlab Solutions, Nelson Pine Industries, and XLam, all of which have been commissioned in the last $5 \mathrm{yr}$, to provide a prefabrication capability. Currently these plants exclusively use Radiata pine for feedstock.

In Australia, there are several manufacturers of generic timber products used in building 
applications, these include, Hyne (Timber framing and Glulam), Australian Sustainable Hardwoods (Hardwood Glulam), Carter Holt Harvey (I-Joist) and Wesbeam (LVL). In total, these manufacturers produce an estimated $150,000-200,000 \mathrm{~m}^{3}$ of LVL per year, whereas it is estimated that Glulam production equates to an estimated 25,000-30,000 $\mathrm{m}^{3} / \mathrm{yr}$. Unlike New Zealand, Australia has several CLT importers and only one established plant for the local production. There are presently three primary importers of CLT (KLH, Binderholz and Stora-Enso), whereas XLam is the only local producer of CLT in Australia and New Zealand. XLam, has announced their new plant in Australia is capable of producing $60,000 \mathrm{~m}^{3}$ per annum, primarily from Radiata pine.

Anecdotally, current estimates regarding the volume of imported CLT range between 25,000 and $40,000 \mathrm{~m}^{3} / \mathrm{yr}$. This is increasing as the demand for the product in Australia and New Zealand increases.

\section{Government Policy and Support}

There was a period where there was quite strong support from the New Zealand central government for MTC. In 2006 the government introduced a "wood-first" policy for government buildings, and provided funding to build demonstration buildings, including the Arts and Media building at the Nelson Marlborough Institute of Technology. The central government also provided funding for Timber Engineering Chairs (professorships) at the Universities of Auckland and Canterbury, and research funding to establish the Structure Timber Innovation Company (STIC) and its research program.

The research benefits of an initiative such as STIC are clear, and the funding described previously led to the demonstration of technical feasibility of MTC. The promotion and extension benefits of such a program are more difficult to define and quantify; however, it is quite likely that the discontinuation of STIC in 2013 and the reduction in financial support from the government may have acted to reduce the uptake of MTC in New Zealand.

More recently, the Rotorua Lakes Council has implemented a Wood-First Policy at the district level. The activities mandated by this policy are as follows:

1. Facilitating and encouraging the use of wood as a preferred, sustainable, building material for all projects in the district.

2. Requiring that wood is used in council projects.

3. Actively supporting and advocating for wood and the wood industry, locally, regionally, and at a national level.... (Rotorua Lakes Council 2015).

The following two tables provide details about a number of projects currently complete or near completion in Australia and New Zealand (Tables 1 and 2).

WHAT ARE SOME OF THE BARRIERS TO GREATER ADOPTION OF MASS TIMBER?

\section{Consumer Barriers}

Kremer and Symmons (2015) identified a particular "gap" in the current knowledge requiring an examination of consumer perceptions about the use of wood as a construction material and how this affects MTC uptake in Australia. They conducted a survey to explore Australian consumers' $(N=281)$ attitudes toward a number of identified factors that may constrain the widespread adoption of MTC in Australia (Kremer and Symmons 2016). Specifically, that study explored the relationship between consumer attitudes toward the environment, the use of timber construction, and factors relating to property purchasing decisions. The results from that study suggest anthropocentric attitudes-when consumers believe that the environment and natural resources should be used to benefit the lives of citizens-mediate, or better explain, the relationship between positive attitudes toward timber in construction (sustainability, durability, structural properties, and economics) and financial factors involved in making a property 
Table 1. Recently completed mass timber buildings in Australia.

\begin{tabular}{|c|c|c|c|c|c|}
\hline Building name & Completed & Location & Storys & $\begin{array}{c}\text { Public } \\
\text { building? }\end{array}$ & Timber features \\
\hline The Good Shed & 2011 & Southbank, Melbourne & 2 & $\mathrm{Y}$ & LVL box truss system and I-joists \\
\hline Forte & 2012 & Docklands, Melbourne & 10 & $\mathrm{~N}$ & $\begin{array}{l}\text { Full CLT design, honeycomb } \\
\text { construction }\end{array}$ \\
\hline The Green & 2013 & Parkville, Melbourne & 6 & $\mathrm{~N}$ & $\begin{array}{l}\text { TecBeam, LVL Cassette flooring } \\
\text { system with light timber framing }\end{array}$ \\
\hline Library at the Dock & 2013 & Docklands, Melbourne & 2 & $\mathrm{Y}$ & CLT and Glulam \\
\hline Netball Central & 2014 & Sydney & 1 & $\mathrm{Y}$ & 40 m clear span LVL portal \\
\hline $\begin{array}{l}\text { International } \\
\text { House }\end{array}$ & 2017 & Barangaroo, Sydney & 6 & $\mathrm{Y}$ & $\begin{array}{l}\text { CLT, Glulam and glass curtain } \\
\text { wall system }\end{array}$ \\
\hline $\begin{array}{l}\text { Monash University } \\
\text { Business School }\end{array}$ & 2017 & Caulfield, Melbourne & 4 & $\mathrm{~N}$ & $\begin{array}{l}\text { CLT vertical extension on top of } \\
\text { an existing concrete structure. }\end{array}$ \\
\hline Aveo Norwest & 2018 & Hills Shire, Sydney & 10 & $\mathrm{Y}$ & $\begin{array}{l}\text { CLT structure comprising a } \\
\text { multifunction center, library, } \\
\text { restaurant and cafe, wellness } \\
\text { center, and } 449 \text { independent } \\
\text { living units over } 10 \text { buildings } \\
\text { of varying heights (4-9 storys) } \\
\text { and a } 144 \text { bed residential aged } \\
\text { care facility }\end{array}$ \\
\hline $\begin{array}{l}\text { The Gardens, } \\
\text { McAuthor }\end{array}$ & 2018 & Campbelltown, Sydney & 6,7, and 8 & $\mathrm{~N}$ & Full CLT design, honeycomb construction \\
\hline
\end{tabular}

CLT, cross-laminated timber; LVL, laminated veneer lumber.

purchasing decision such as monthly repayments, interest rates, return on investment, and cost of insurance.

To overcome some of the barriers related to consumer perceptions, Kremer and Symmons (2016) outlined several recommendations, including the following:

1. Presenting "green" information. It was insufficient for property developers, real estate marketers etc. to provide a "Green Star" rating in isolation to additional information. Australian consumers indicated that such a rating system was not a great influence in property purchasing decisions. However, the development of a composite of "green" information about the environmental attributes and sustainable design practices inherent within MTC buildings might be of significant value. It seems that consumers want to understand and be educated about the qualities of the property they intend to purchase and how this contributes to environmental efforts.

2. Age matters when it comes to attitudes toward timber. There were noticeable differences in attitudes between older and younger adultstoward structural soundness and construction components (bricks, timber, steel, and concrete). Some evidence of a potential generational shift in thinking about building and construction seems to exist, according to Kremer and Symmons (2016). As such, it appears important to present messages to younger adults about the structural soundness and environmental benefits of MTC, yet for older adults, there appears to be an inherent support for timber use in construction. Targeting specific marketing messages by age segmentation (as well as along environmental attitudinal lines) could be used to great effect in marketing MTC consumers.

3. Finally, overcoming prejudices about the durability of timber in construction through clearly articulated marketing communication messages is vitally important. It appears consumers do not understand that commonly CLT - and other mass timber products - are covered with interior wall lining and exterior cladding (allowing for compliance to fire and acoustic codes and regulations), nor do they 
Table 2. Recently completed mass timber buildings in New Zealand.

\begin{tabular}{|c|c|c|c|c|c|}
\hline Building name & Completed & Location & Storys & $\begin{array}{l}\text { Public } \\
\text { building? }\end{array}$ & Timber features \\
\hline $\begin{array}{l}\text { Waitomo Caves Visitor } \\
\text { Center }\end{array}$ & 2009 & Waitomo & 1 & $\mathrm{Y}$ & LVL grid-shell structure \\
\hline $\begin{array}{l}\text { NMIT Arts and Media } \\
\text { Building }\end{array}$ & 2010 & Hardy Street, Nelson & 3 & $\mathrm{Y}$ & $\begin{array}{l}\text { Posttensioned LVL shear walls, LVL } \\
\text { gravity frames, and timber floors }\end{array}$ \\
\hline Events Center & 2011 & Carterton & 2 & $\mathrm{Y}$ & $\begin{array}{l}\text { LVL long-span truss and LVL } \\
\text { posttensioned shear walls }\end{array}$ \\
\hline $\begin{array}{l}\text { MOTAT Aviation Display } \\
\text { Hall }\end{array}$ & 2011 & Auckland & 1 & $\mathrm{Y}$ & LVL portal \\
\hline $\begin{array}{l}\text { Massey University COCA } \\
\text { Building }\end{array}$ & 2012 & Wellington & 3 & $\mathrm{Y}$ & Posttensioned LVL beams and columns. \\
\hline Tumu ITM & 2012 & Napier & 1 & $\mathrm{~N}$ & LVL portal frames \\
\hline Merritt Building & 2013 & $\begin{array}{r}\text { Victoria Street, } \\
\text { Christchurch }\end{array}$ & 3 & $\mathrm{~N}$ & Posttensioned LVL beams and columns \\
\hline Trimble Building & 2014 & $\begin{array}{l}\text { Birmingham Drive } \\
\text { Christchurch }\end{array}$ & 2 & $\mathrm{~N}$ & $\begin{array}{l}\text { Posttensioned LVL shear walls and } \\
\text { columns. }\end{array}$ \\
\hline Lucas House & 2014 & Halifax Street, Nelson & 2 & $\mathrm{~N}$ & LVL timber gravity frames \\
\hline The Warehouse & 2014 & Richmond & 2 & $\mathrm{~N}$ & $\begin{array}{l}\text { CLT LVL shear walls and LVL timber } \\
\text { gravity frames }\end{array}$ \\
\hline Wynn Williams Building & 2015 & $\begin{array}{l}\text { Montreal Street, } \\
\text { Christchurch }\end{array}$ & 6 & $\mathrm{~N}$ & $\begin{array}{l}\text { Posttensioned LVL beams (posttensioned } \\
\text { concrete columns) }\end{array}$ \\
\hline $\begin{array}{l}\text { Tait Communications } \\
\text { Building }\end{array}$ & 2015 & $\begin{array}{l}\text { Roydvale Street, } \\
\text { Christchurch }\end{array}$ & 2 & $\mathrm{~N}$ & LVL timber gravity frames \\
\hline $\begin{array}{r}\text { Bealey Avenue } \\
\text { Backpackers }\end{array}$ & 2015 & $\begin{array}{l}\text { Bealey Avenue, } \\
\text { Chrischurch }\end{array}$ & 2 & $\mathrm{~N}$ & $\begin{array}{l}\text { CLT honeycomb structure and LVL } \\
\text { beams }\end{array}$ \\
\hline ACC Building & 2015 & Rotorua & 2 & $\mathrm{Y}$ & $\begin{array}{l}\text { CLT tilt slabs, LVL beams and columns, } \\
\text { and CLT floors }\end{array}$ \\
\hline Bed Bath and Beyond & 2015 & Richmond & 1 & $\mathrm{~N}$ & $\begin{array}{l}\text { CLT/LVL shear walls, LVL timber } \\
\text { gravity frames, and composite } \\
\text { concrete/LVL floor system }\end{array}$ \\
\hline Mt Pleasant Center & 2016 & Mt Pleasant, Christchurch & 1 & Y & LVL "folded wave" structure \\
\hline Kaikoura Museum & 2016 & Kaikoura & 3 & $\mathrm{Y}$ & $\begin{array}{l}\text { CLT/LVL shear walls, LVL post and } \\
\text { beam gravity frames, and LVL floors }\end{array}$ \\
\hline $\begin{array}{l}\text { Kahukura Building, Te } \\
\text { Ara }\end{array}$ & 2017 & $\begin{array}{l}\text { Moorehouse Avenue, } \\
\text { Christchurch }\end{array}$ & 4 & $\mathrm{Y}$ & $\begin{array}{l}\text { LVL timber gravity frames and CLT } \\
\text { façade. }\end{array}$ \\
\hline
\end{tabular}

CLT, cross-laminated timber; Glulam, glue laminated timber; LVL, laminated veneer lumber.

understand the inherent fire-resisting properties of timber. Education is required by developers and realtors to overcome consumer prejudices about MTC projects promoted as "timber structures."

\section{Industry Barriers}

Industry barriers include increased professional risk for engineers and architects associated with specifying new or innovative materials or methods of construction. Evison (2015) reported that existing building codes and standards in New Zealand did not explicitly accommodate the new wood technologies. This was seen as a barrier-leading to higher design costs, the need to use and commission research to find solutions, and the need for peer review of alternative solutions. This also was seen to have a consequence of more conservative and therefore more expensive design. These barriers and issues have been experienced in other countries and have been echoed in a recent report, describing the results of a survey on timber buildings, in Europe and Australia (Forestry Innovation Investment and Binational Softwood Lumber Council 2014).

To grow the market for timber buildings there needs to be both demand and capacity. For continued 
investment in the manufacturing facilities the manufacturers need to be aware of the developing market place and potential new buildings. In turn, those involved in buildings at the concept stage need to engage manufacturers early to ensure that there is capacity to produce the required building elements to a suitable schedule.

\section{WHAT ARE SOME OF THE BENEFITS OF GREATER ADOPTION OF MASS TIMBER?}

1. Wood quality and other feedstock considerations.

2. Environmental benefits-green star, carbon sequestration, operational costs, and internal environment.

3. Other.

\section{Wood Quality and Feedstock Considerations}

Across Australia and New Zealand, the primary feedstock species is Radiata pine, a widely grown softwood with excellent properties for machining, and adequate strength values. The limiting factor in the use of Radiata pine for manufacturing structural panels is usually stiffness. The manufacture of LVL provides a significant increase in strength and stiffness, through the removal of defects, and the measurement and segregation of veneers by stiffness. Radiata pine is also the material of choice for Glulam in Australia and New Zealand, however, it is very costly to purchase high-stiffness feedstock, which increases the cost of this product compared with that produced by European (EU) manufacturers.

European suppliers of CLT also use stiffer softwood timber, and the cost of imported EU CLT about the same as the domestic Australian or New Zealand product. Thus, it is likely that EUsupplied CLT is going to be a permanent competitor in the local markets, based on price and cost alone.

One advantage that Radiata pine has over its EU counterpart feedstock is the ability to treat the product. The different cell structure of the locally grown pine compared with the EU, typically spruce, allows the Australian and New Zealand feedstock the ability to be treated for durability. For example, in a bathroom environment the floors of the wet areas can be treated with H3.0 (Australia) or H3.2 (New Zealand) chemical treatment that allows increased protection against water ingress. Therefore, the equation between cost and value requires a focus on not only the cost of the feedstock relative to the MOE however also in terms of other factors, such as the ability to treat product. The equation becomes more complex than a simple feedstock to feedstock comparison.

\section{Environmental Benefits}

The environmental benefits of MTC are not currently accorded much value by the market. Page (2007) also stated that the "Green Star Office rating scheme is not particularly supportive of timber structures as such, and timber materials achieve a small effect on the overall rating of a building, compared to the BREEAM (Building Research Establishment Environmental Assessment Method) rating scheme in the UK..." Buchanan et al (2012) did a comparison using life cycle analysis of an existing timber building with an alternative in steel or reinforced concrete. A key finding was that "the operation of buildings (rather than production and disposal of materials or building maintenance) is the dominant contributor to both lifetime energy consumption and global warming potential (GWP), although this is reducing as modern buildings become increasingly energy efficient...." They also state that "....operational energy and maintenance energy are almost independent of structural materials for well-designed conventional buildings..." Because of this, any energy savings through using MTC are dominated by the lifetime energy consumption.

It is likely that changes to environmental certification systems currently underway (including environmental product declarations) will highlight the benefits of wood construction better, by explicitly allowing for the comparative carbon footprints of different materials. This point was also taken up by Buchanan et al (2012): “...A 
carbon footprint calculation is proposed for incorporation into green building rating schemes such as Green Star. This calculation should concentrate on GWP of material production and disposal because this is not included in current Green Building assessment tools, whereas such tools already give points for low operational energy..."

This may occur as society recognizes the value of wood as a carbon store, and the opportunity to store carbon in wooden structural components for building. This would require a more rigorous government policy approach to reducing carbon emissions than is currently the case in both New Zealand and Australia. However, net emissions from harvested wood products are accounted for in New Zealand's Greenhouse Gas Inventory (Ministry for the Environment, 2016a) and New Zealand is intending to recognize harvested wood products when accounting for its 2021-30 target under the Paris Agreement. How harvested wood products might be accounted for in the New Zealand Emissions trading scheme has not yet been decided (Ministry for the Environment, 2016b).

\section{Other}

There are a number of clear advantages and a solid, although not yet mature, market in Australia and New Zealand. Some of the challenges or barriers of entry include a lack of local expertise-especially in design and construction-and the absence of relevant construction and engineering standards. Arguably, standards committees are under- or illprepared for the disruption of and uptake of the technology, however, this is not solely a problem in Australia and New Zealand, rather, it is a more global phenomenon. Internationally, there is a considerable undertaking by construction industry stakeholders in nations keen to adopt MTC as a more mainstream material/method to develop or adopt appropriate standards to progress the technology. For example, the Building Code of Australia allows for the provision of other standards, including European and Canadian codes, to be used in an alternative solution situation.

\section{CONCLUSIONS}

Mass timber construction is a technological innovation with the potential to disrupt the construction industry in Australia (Kremer and Symmons 2015) and New Zealand. MTC uses engineered-timber products as the primary structural material. Typically, MTC can be substituted for concrete, whether it is wet-poured, steel reinforced, or solid section "tilt-slab" for low- to medium-rise buildings-hotels, vertical extensions, and accommodation facilities-and for public buildings such as libraries and schools. In more recent times, mass timber panels and components have been specified for use in detached residential housing projects, specifically of a high-end nature or as floor systems or intertenancy partition wall components, rather than complete systems.

Although a great deal of interest is being shown in MTC technology, anecdotally, suppliers of MTC products are facing difficulties in the promotion of its use because of the very different approach required in the design and construction building of MTC compared with the more traditional steel and concrete. Challenges await the uptake of MTC, including establishing supply chains, amassing assembly and engineering expertise, and a required shift in accepted marketing and sales models. As with any new technology, new routes to market need to be established for MTC. In Australia, the supply chain/s for MTC are currently very insular (Kremer and Symmons 2015). Typically, the developer or builder contain and action the entire process from design, engineering, procurement, and installation to manage the risks that would otherwise be associated with a more disparate supply chain.

The adoption of MTC as a mainstream process or method requires a differentiated approach in terms of sales and marketing. Methods for quoting and financing more traditional projects have been established over many years; however, such processes are not entirely appropriate for supporting massive timber structures. An important consideration for the promotion of MTC is the "total cost of ownership" or "business case" 
calculation that includes not only the material costs (the substitution of timber for reinforced concrete). In Australia, the cost of financing offsite payments for material produced and not yet installed on-site, because of issues of readiness to accept deliveries of panels and other elements, is quite novel, requiring a holistic solution-for banks, customers, developers/investors, and building contractors.

In Australia and New Zealand, mass timber building technology has moved from being technologically possible to being seen as a feasible alternative to reinforced concrete and steel construction. It has not taken over a large market share in either market, and as such has not been a disruptive technology. There are clearly still barriers to overcome to reduce the perceived cost of building in wood, and to reduce the real or perceived professional risk of moving from the traditional materials.

Some of the benefits of MTC are not currently highly valued by the market. These include convenience for construction (generated by the lack of dust, wet work, and by the use of lighter materials), appearance and influence on the work environment, effects on human health and wellbeing, and environmental aspects such as carbon footprint.

The New Zealand government, in conjunction with the industry, has encouraged timber engineering research and development. Government financial support for multistory timber buildings increases practical knowledge and experience, which reduces professional risk for engineers and architects and stimulates public interest. A "wood first" policy and financial support for research and the development of standards and design guides are appropriate actions that governments can take to encourage mass timber systems.

We are still at the stage where mass timber buildings are owner-specified, rather than recommended by engineers and architects. The design and build model will facilitate greater use of wood, and provide better control over the supply chain. Different business models (including industrial clusters of related and supporting industries), better control of the supply chain from design to construction to better leverage the advantages of building in wood, and increased expertise in prefabrication should all encourage great use of mass timber in construction.

It is believed that the engineering expertise in timber building will continue to develop and mature as engineers and architects develop a better understanding of this unique natural material. Whether greater use of wood comes about from process and technological improvements, or a greater societal appreciation and need for the benefits of wood is an open question. Whether Australia and New Zealand develop "a culture of wood architecture" for multistory buildings (Taggart 2011) is also an open question, but for the proponents of this technology, this is clearly a worthy objective.

\section{ACKNOWLEDGMENTS}

The authors would like to thank Professor Andy Buchanan and Dr. Robert Finch (University of Canterbury), Dr. Tobias Smith (Pre-stressed Timber Ltd., Christchurch), Andrew Irving (Irving Smith Architects, Nelson), and Sam Leslie (XLam, Nelson) for their generosity in sharing their knowledge and experience. Any errors or inaccuracies are the responsibility of the authors.

\section{REFERENCES}

Buchanan AH, John S, Love S (2012) LCA and carbon footprint of multi-storey timber buildings compared with steel and concrete buildings. Proc. World Conference on Timber Engineering, July 16-19, Auckland, New Zealand. Quenneville P. (ed.). pages 92-100, New Zealand Timber Design Society, New Zealand.

Bruneau M, MacRae G (2017) Reconstructing Christchurch: A seismic shift in building structural systems. The Quake Centre, University of Canterbury, Christchurch.

Depro BM, Murray BC, Alig RJ, Shanks A (2008) Public land, timber harvests, and climate mitigation: Quantifying carbon sequestration potential on U.S. public timberlands. For Ecol Mgmt 255(3):1122-1134.

Dunn A (2015) Final report for commercial building costing cases studies: Traditional design versus timber project. Report no. PNA308-1213. Forest and Wood Products Australia, Melbourne, Australia. 
Evison D (2015) Survey of key decision-makers involved in the construction of multi-storey timber buildings in Christchurch during 2013 and 2014. Timber Design Journal 22(4): 15-22.

Forestry Innovation Investment and Binational Softwood Lumber Council (2014) Survey of international tall wood buildings. http://www.rethinkwood.com/sites/default/files/ wood-resource-pdf/Survey\%20Tall\%20Wood_REPORT\% 20WITHOUT\%20APPENDICIES_web.pdf (15 August 2015).

Kremer PD, Symmons MA (2015) Mass timber construction as an alternative to concrete and steel in the Australia building industry: A PESTEL evaluation of the potential. Int Wood Prod J 6(3):138-147.

Kremer PD, Symmons MA (2016) Overcoming psychological barriers to widespread acceptance of mass timber construction in Australia. Report no. PNA309-1213. Forest \& Wood Products Australia Limited, Melbourne, Australia. Lehmann S, Fitzgerald GB (2012) Sustainable urban infill development using low-carbon prefabricated timber construction systems: Wood in the city. Sustainability 4: 2707-2742.

McGregor RM, Evison D, Ozanne L (2011) A pilot survey of structural engineers' perceptions of laminated veneer lumber in single-storey industrial buildings. SESOC Journal 24(1):25-28.

Ministry for the Environment (2016a) New Zealand's greenhouse gas inventory, 1990-2014. Fulfilling reporting requirements under the United Nations framework convention on climate change and the Kyoto protocol. New Zealand Government, Wellington, New Zealand.

Ministry for the Environment (2016b) The New Zealand emissions trading. New Zealand Government, Wellington, New Zealand.

Page I (2007) Timber structural use potential in nonresidential buildings. BRANZ Report E465. BRANZ Ltd, Porirua City, New Zealand.

Rotorua Lakes Council (2015) Wood first policy. http://www. rotorualakescouncil.nz/our-council/PoliciesandBylaws/ Policies/Pages/default.aspx (21 May 2018).

Taggart J (2011) Toward a culture of wood architecture. Abacus editions, Vancouver, British Columbia.

Wood Solutions (2013) Why wood? Strength performance. http://www.woodsolutions.com.au/Articles/Why-Wood/ product-performance-strength (30 June 2015).

Yates M, Linegar M, Dujic B (2008) Design of an 8 storey residential tower from $\mathrm{KLH}$ cross laminated solid timber panels. http://www.ewpa.com/Archive/2008/june/Paper_ 299.pdf (24 May 2015). 